\title{
Oral Mucositis: Melatonin Gel an Effective New Treatment
}

\author{
Ahmed Esmat Abdel Moneim ${ }^{1}$, Ana Guerra-Librero ${ }^{2}$, Javier Florido ${ }^{2}$, Ying-Qiang Shen ${ }^{2}$, \\ Beatriz Fernández-Gil ${ }^{2}$, Darío Acuña-Castroviejo ${ }^{2,3}$ and Germaine Escames ${ }^{2,3, *}$ \\ 1 Department of Zoology and Entomology, Faculty of Science, Helwan University, 11795 Cairo, Egypt; \\ aest1977@hotmail.com \\ 2 Centro de Investigación Biomédica, Universidad de Granada, 18016 Granada, Spain; \\ ana_guerra-librero@hotmail.com (A.G.-L.); jflorido@correo.ugr.es (J.F.); \\ shenyingqiang@outlook.com (Y.-Q.S.); beatrizirenefg@correo.ugr.es (B.F.-G.); dacuna@ugr.es (D.A.-C.) \\ 3 CIBERfes, Ibs.Granada, and UGC de Laboratorios Clínicos, Complejo Hospitalario de Granada, \\ 18014 Granada, Spain \\ * Correspondence: gescames@ugr.es; Tel.: +34-618-521-646 \\ Academic Editor: Russel J. Reiter \\ Received: 8 March 2017; Accepted: 3 May 2017; Published: 7 May 2017
}

\begin{abstract}
The current treatment for cervico-facial cancer involves radio and/or chemotherapy. Unfortunately, cancer therapies can lead to local and systemic complications such as mucositis, which is the most common dose-dependent complication in the oral cavity and gastrointestinal tract. Mucositis can cause a considerably reduced quality of life in cancer patients already suffering from physical and psychological exhaustion. However, the role of melatonin in the treatment of mucositis has recently been investigated, and offers an effective alternative therapy in the prevention and/or management of radio and/or chemotherapy-induced mucositis. This review focuses on the pathobiology and management of mucositis in order to improve the quality of cancer patients' lives.
\end{abstract}

Keywords: mucositis; radiotherapy; chemotherapy; pathophysiology; management; melatonin

\section{Overview of Mucositis Pathobiology}

Mucositis, one of the most severe toxic side effects of cancer therapy, can affect the entire gastrointestinal tract, with the oral cavity being the most common affected site. It presents in virtually all head and neck cancer patients receiving chemo and/or radiotherapy, in $60-85 \%$ of those receiving myeloablative therapy for stem-cell transplantation, and in $20-40 \%$ of patients receiving conventional chemotherapy [1-3]. The use of concomitant chemotherapy and/or targeted agents increases the risk of mucositis.

Oral lesions lead to considerably decreased quality of life in these patients due to solid and liquid food dysphagia, dysarthria, and odynophagia, resulting in depression in some patients, who often require percutaneous endoscopic gastrostomy tube insertion [4]. In addition, mucositis lesions may represent a gateway for opportunistic infections, can complicate cancer treatment, and extend hospitalization [5,6]. On the other hand, given its dose-limiting toxicity for both chemo and radiotherapy, mucositis can have a direct impact on survival rates [7].

\section{Pathophysiology of Mucositis}

Recent developments in mucositis research have highlighted multiple factors which contribute to mucosal injury [8]. A five-phase chronological process has been proposed: initiation, primary damage response (upregulation and message generation), signal amplification, ulceration, and the healing phase [9]. Mucositis commences when gastrointestinal (GI) mucosa are exposed to cytotoxic agents, 
resulting in cellular DNA damage and cell death, mainly through the generation of oxidative stress and reactive oxygen species (ROS) formation. ROS directly induce tissue injury and trigger a cascade of inflammatory pathways [10]. Ortiz et al. have also observed a mitochondrial oxidation response to radiation with subsequent mitochondrial dysfunction [11].

The progression of mucositis is characterized by significant inflammatory mediator up-regulation due to the activation of the NF- $\mathrm{KB}$ pathway (upregulation and message generation phase). This is followed by the signaling and amplification phase, during which, once activated by chemotherapy and ROS, NF- $\mathrm{KB}$ promotes the expression of multiple pro-inflammatory molecules, including inducible nitric oxide synthase (iNOS), cyclooxygenase-2 (COX-2), TNF- $\alpha$, and pro-IL-1 $\beta$, and ensures feedback amplification of the NF-kB-dependent signaling pathway [10]. Furthermore, mitochondrial ROS production promotes inflammation by activating a multi-protein cytoplasmic complex, such as the NLRP3 (NACHT, LRR, and PYD domains-containing protein 3) inflammasome. NLRP3 inflammasome assembly leads to caspase- 1 activation and subsequent cleavage of pro-cytokines such as pro-IL-1 $\beta$, pro-IL-18, and pro-IL-33 into their mature form [11,12] resulting in ulceration (ulceration phase). Therefore, the NF- $\mathrm{kB}$ pathway, mitochondrial dysfunction, and subsequent NLRP3 inflammasome activation are the three main players involved in the development of oral mucositis, which amplify the whole inflammatory process via positive feedback loops, thus prolonging tissue injury and ending in the healing phase.

During the initiation phase of mucositis, patients begin to develop erythema followed by focal areas of oral mucosal desquamation [13], which mainly occur at the submucosa and basal epithelium level. Therefore, although no evident damage to mucosal integrity is observed clinically, the tissue biology is altered [10]. The progression of mucositis is then prolonged and severe, mucosal integrity is breached, ulceration begins to form and the patient starts to have a burning sensation. Atrophic changes occur in the GI mucosa, culminating in tissue injury and stem cell death. GI epithelial integrity and function are destroyed and impaired, respectively. A fibrinous exudate, or pseudomembrane, containing bacteria covers the ulcer. Bacterial colonization at the mucosa ulcers further induces inflammation by stimulating infiltration and activation of macrophages, which occurs approximately two weeks after therapy [10]. Cell wall residues originating from colonizing bacteria penetrate the submucosa, where they activate macrophages in the infiltrate [14]. This can lead to prolonged hospitalization, the need for parenteral nutrition, severe pain, risk of infection and sepsis, and increased risk of morbidity and mortality.

The final stage of mucositis pathobiology is the healing process. Epithelial cells controlled by signals secreted by the extracellular matrix, which are then downregulated to avoid hyperplasia, migrate, grow, and differentiate to form a wound. With the healing process under way, symptoms begin to abate [9], and healing is completed within 4 weeks after the final dose of radiation. Unfortunately, even after full replenishment of the epithelium, the structure of the reconstituted submucosa differs from its pre-radiotherapy state [15].

Intestinal mucositis is also a common side effect of anticancer chemotherapy that involves the small intestines. In intestinal mucositis, histopathological changes are also associated with the production of ROS and the amplification of inflammatory signals induced by anticancer drugs or radiation. Keefe et al. [16] studied patients undergoing chemotherapy with sequential duodenal biopsies pre and post treatment. They found that an increase in apoptosis was the first histological effect to be noted, with a seven-fold increase in apoptosis in intestinal crypts at day one post treatment. Reduction of the intestinal villous area, crypt length, and crypt proliferation then followed and the maximal effect was observed 3 days post treatment. Research is ongoing to fully elucidate the mechanisms of intestinal mucositis. The loss of crypt stem cells remains an important event in intestinal injury following anticancer treatment. However, it is not the sole contributing factor leading to overt damage. The inflammatory cascade is being realized as an important pathway in the development of intestinal mucositis that can be pharmacologically manipulated [17]. 
On the other hand, radiation-induced damage to healthy intestine tissue is a common side-effect caused by out-of-field or scattered radiation [18]. We recently demonstrated that tongue irradiation also induces intestinal damage. Typical macroscopic traces of mucositis were also detected in the small intestines of irradiated animals, including a significant decrease in villus height and morphological alterations associated with substantial intestinal architecture changes [19]. Given the involvement of mitochondrial oxidative stress, bio-energetic impairment, and subsequent NLRP3 inflammasome activation in the development of radiotherapy-induced gut toxicity, the oral irradiation of rats also resulted in increased small intestinal damage.

\section{Mucositis Management}

As there is no effective therapy for mucositis or its associated pain, a large number of studies have been conducted in this field. Strategies for managing oral mucositis include preventative measures and therapeutic approaches (Figure 1) [13].

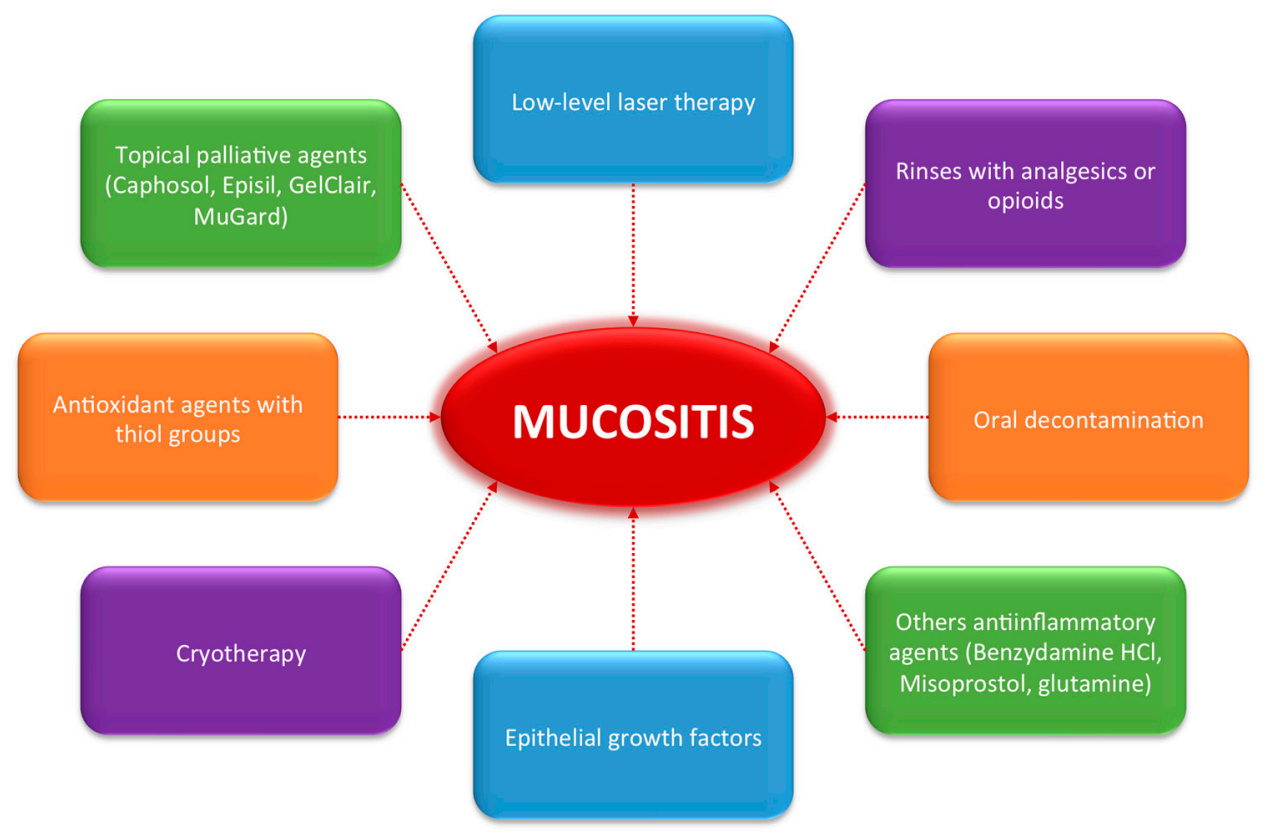

Figure 1. Actual strategies for managing oral mucositis.

Current supportive measures to reduce the risk and severity of oral mucositis include improved oral hygiene, which eliminates the presence of any irritants to the oral mucosa [20]. Systemic analgesics are also recommended, as tissue injury activates nociceptive receptors which increase pain alongside the underlying tissue damage [7].

Several topical palliative agents, including Caphosol, Episil, GelClair, and MuGard, have been approved for the treatment of mucositis, are aimed at alleviating pain and improving the patient's quality of life. However, data on the efficacy of these agents in controlling mucositis-related symptoms are scarce [13,21-24].

A combination of treatments, such as local rinses with a $2 \%$ viscous lidocaine solution, magic mouthwash preparations, a topical morphine solution, and other systemic analgesics are used to control pain [25]. Frequent rinsing with sodium chloride solution helps to keep the mucosa moist, reduces caking of secretions, and soothes inflamed/ulcerated mucosa. An oral rinse containing doxepin appears to be effective for easing acute oral mucositis pain caused by radiation therapy (with or without chemotherapy) [26]. However, there is no significant evidence to suggest that these mouthwashes are effective [27]. Another type of topical agent is the transdermal patch, composed of fentanyl, which is 
a potent, fast, and short acting synthetic opioid analgesic, although transdermal fentanyl causes mild dizziness, gastrointestinal reactions, and itching [28].

Oral decontamination, involving treatments such as Nystatin and chlorhexidine [29], may result in significant positive outcomes in the prevention of ulcerations linked to oral mucositis. Recently, Silva et al. [30] tested a soft pastille formulation consisting of $0.25 \%$ lidocaine and 78,000 IU Nystatin, which was found to facilitate accurate drug administration by physicians and to enable patients to control drug retention time in the mouth in order to manage the pain treatment process. On the other hand, chlorhexidine is an effective broad-spectrum antiplaque antiseptic agent [31]. However, these drugs are not very effective in reducing the severity or incidence of mucositis [32,33].

Cryotherapy, during which patients suck on ice chips for $30 \mathrm{~min}$ prior to and during chemotherapy infusion [34-37], has been shown to effectively attenuate the onset and severity of mucositis in patients undergoing chemotherapy with 5-fluorouracil and melphalan. However, it is only effective for short bolus chemotherapeutic infusions [38], may not be tolerated by some subjects, and thus cannot play a significant role in radiation-induced oral mucositis treatments [25].

Several antioxidant agents to prevent mucositis or to reduce its severity have been tested. One of the first drugs used to treat mucositis was amifostine [13], a thiol compound which is dephosphorylated to an active metabolite and acts as a potent ROS scavenger. However, given its limited and inconsistent results, amifostine is not recommended for the prevention of oral mucositis in patients receiving either chemotherapy or radiotherapy alone [39]. $N$-acetyl cysteine (NAC) is another antioxidant containing thiol groups, which stimulates glutathione synthesis and scavenges free radicals. In addition to its antioxidant properties, NAC prevents NF- $\mathrm{KB}$ activation which increases the inflammatory response. In a double-blind, randomized, placebo-controlled trial, NAC significantly reduced severe oral mucositis incidence [40].

Given that a reduction in the proliferative capacity of oral epithelial cells is thought to play a role in mucositis pathogenesis, various growth factors capable of increasing epithelial cell proliferation have been studied with regard to oral mucositis management. Although palifermin, an epithelial-specific growth factor, is the only agent approved for the prevention of oral mucositis in bone-marrow transplant patients [41], it is also associated with adverse side effects, requires intravenous administration, and is expensive [42]. Other growth factors, such as velafermin, filgrastim, and argramostim, have been analyzed for use in the treatment of mucositis [43]. Smad7, which has recently received considerable attention [44], was initially identified as a TGF- $\beta$ superfamily signaling antagonist, which blocks TGF- $\beta$-induced growth inhibition and apoptosis in keratinocytes [45] and reduces inflammation by antagonizing NF- $\mathrm{kB}$ activation. All of these characteristics may make Smad7 beneficial in the treatment of oral mucositis [44].

Several anti-inflammatory agents have produced good results in studies of oral mucositis in animals; there is still conflicting evidence, however, on the efficacy of these agents in reducing the severity of mucositis in humans [13]. Benzydamine $\mathrm{HCl}$ is a non-steroidal anti-inflammatory drug that inhibits pro-inflammatory cytokines including TNF- $\alpha$, and IL-1 $\beta$. It has been administered in an intravenous formulation recommended for the prevention of oral mucositis in patients with head and neck cancer receiving moderate-dose radiation therapy without concomitant chemotherapy [46]. A long list of anti-inflammatory drugs has produced inconsistent results with regard to the prevention of chemotherapy-induced oral mucositis. This is the case for Misoprostol, a synthetic prostaglandin E1 analog, which has anti-inflammatory mucosa protection properties. However, the overall results of using misoprostol mouthwash in the prevention of radiation-induced oral mucositis in head and neck cancer patients were negative $[47,48]$. While glutamine, a nonessential amino acid, may mitigate mucosal injury by reducing pro-inflammatory cytokine production and cytokine-related apoptosis [49,50], it produced inconsistent results in the prevention of chemotherapy-induced oral mucositis [51-53].

Multiple studies have indicated that the application of low-level laser therapy (LLLT) reduces the incidence and, by hastening oral re-epithelialization, favorably influences oral mucositis 
outcomes in patients undergoing standard, hematopoietic stem cell transplantation and myeloablative chemotherapy [54-59]. Although the mechanism involved in these benefits is not understood, it has been suggested that LLLT may reduce ROS and/or pro-inflammatory cytokine levels which contribute to mucositis pathogenesis [25]. However, many of the pathways stimulated by LLLT are associated with undesirable tumor behaviors and/or treatment responses [60].

Moreover, there are some exciting approaches to the treatment and prevention of intestinal mucositis that could potentially be extended to the oral mucosa. These include probiotics, probiotic-derived factors, and plant extracts and preparations. A research study conducted by Yeung et al. [61] found that the daily oral administration of a probiotic suspension of Lactobacillus casei variety rhamnosus (Lcr35) or Lactobacillus acidophilus and Bifidobacterium bifidum (LaBi) resulted in the attenuation of diarrhea, proinflammatory cytokines, and jejunal villi damages in 5-FU(fluorouracil) -induced intestinal mucositis. Furthermore, a prospective open-labeled randomized trial in Sweden documented that Lactobacillus rhamnosus administration twice daily for 24 weeks reduced grade 3 or 4 diarrhea in patients and minimized the hospitalization due to bowel toxicity [62]. However, a major limitation of the Osterlund et al. [62] study was the lack of blinding and placebo control. A large prospective, double-blinded, placebo-controlled randomized trial at a single institution in Italy investigating the role of probiotics in the prevention of RT-induced acute diarrhea was conducted by Delia et al. [63]. The patients received a VSL $\# 3^{\circledR}$ sachet contained $4.5 \times 10^{11} /$ gram of viable lyophilized bacteria including four strains of Lactobacilli, three strains of Bifidobacteria, and one strain of Streptococcus. The authors found that significant improvements were noted in diarrhea. However, the overall methodology and results are very sparse in detail, limiting the reader's ability to follow the trial.

Finally, traditional Chinese Medicine (TCM) offers empirical herbal formulas for treating mouth ulcers and stomatitis which has frequently been used in the complementary treatment of oral mucositis, but the evidence for these therapies is unclear and in some cases they have not been effective [64]. Also, the standard concepts for this kind of treatment do not exist and the acceptance by conventional oncologists is still low. In western complementary medicine, several herbal treatment approaches exist including Salvia officinalis, Matriciana camomilla, Calendula officinalis, Hamamelis virginiana, Potentilla erecta, Commiphora molmol, Myrtilli fructus, Althaea spps, Malva spps, Cetraria islandica, Linum usitatissimum, Flos caryophylli, Hippophae rhamnoides, Aloe vera, Carica papaya, Centaurii herba, Gentianae radix, Menyanthes folium, Eriodictyon crassifolium, Oleum olivae and Citrus limon. They are applied as single infusions for gargling or topical application [65]. Of these, Matriciana camomilla, Salvia officinalis, Chimonanthus salicifolius, Aloe vera, Gentianae radix and date palm pollen have been used [65-69]. The anti-mucositis activity of different herbs might be due to inhibiting apoptosis and inflammation in GIT (gastrointestinal tract). However, later phase III trials of Matricaria chamomilla have failed to conclude that the chamomile given in mouthwash formulations is effective in patients with chemotherapy-induced mucositis [70]. Table 1 summarizes the different agents used in mucositis management.

Table 1. Studies which evaluated the effect of different agents on the management of mucositis.

\begin{tabular}{|c|c|c|c|c|}
\hline Agent & Experiment & Subject & Outcomes & Reference \\
\hline Traumeel S & $\begin{array}{l}\text { A randomized, controlled clinical trial of the } \\
\text { homeopathic medication Traumeel S in the } \\
\text { treatment of chemotherapy-induced stomatitis in } \\
\text { children undergoing stem cell transplantation }\end{array}$ & Human & $\begin{array}{l}\text { The severity and duration } \\
\text { of chemotherapy-induced } \\
\text { stomatitis were reduced }\end{array}$ & {$[71]$} \\
\hline \multicolumn{5}{|c|}{ Topical agents } \\
\hline
\end{tabular}


Table 1. Cont.

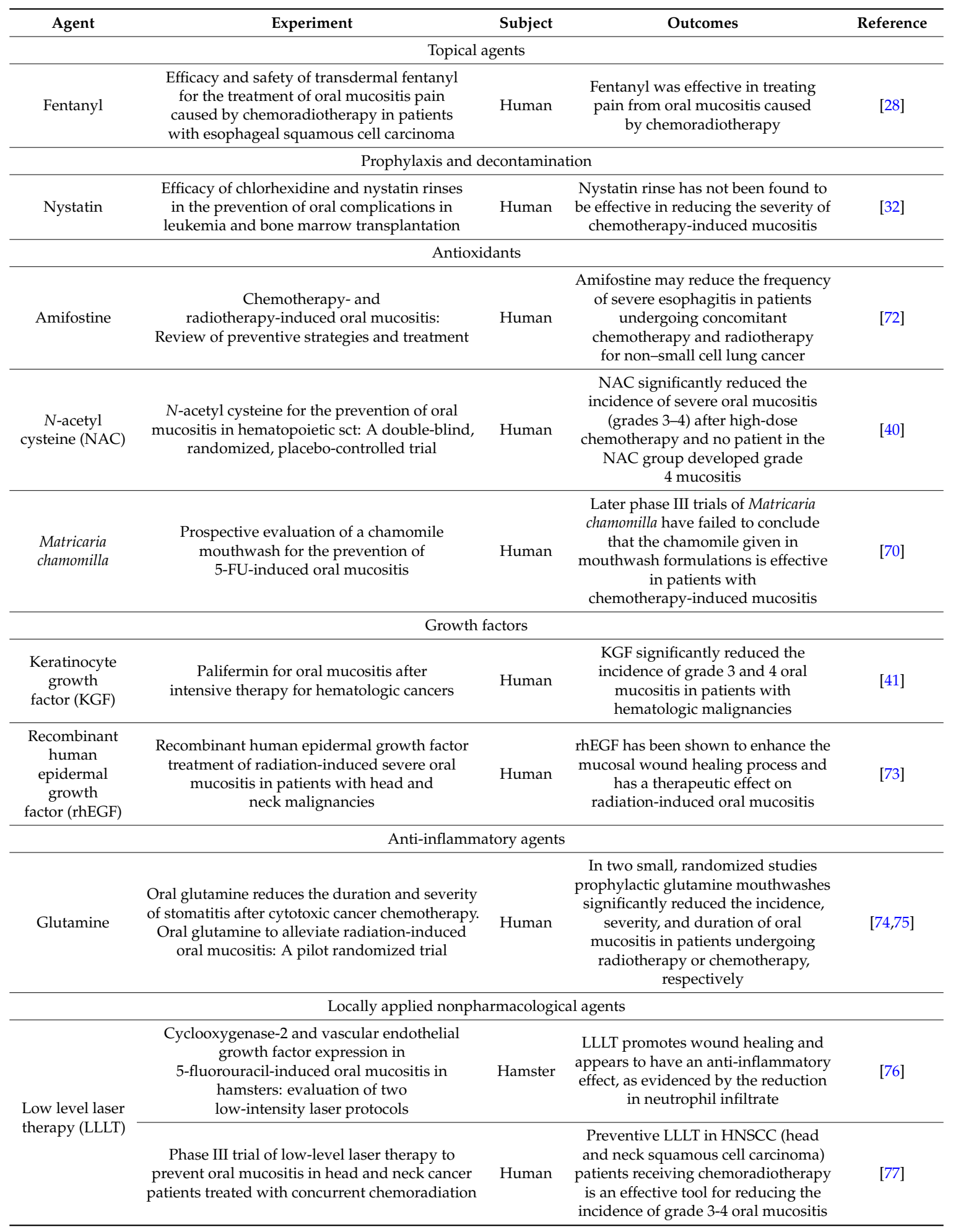

\section{Melatonin: A New Treatment for Mucositis}

Melatonin ( $\mathrm{N}$-acetyl-5-methoxytryptamine), a hormone synthesized from tryptophan, is produced by the pineal gland; it has been detected in multiple extrapineal organ tissues at much higher concentrations than in the pineal gland [78]. It is a potent free radical scavenger with anti-oxidant properties (Table 2), which increases the expression and activity of endogenous antioxidant enzymes 
such as superoxide dismutase (SOD), catalase, glutathione peroxidase (GPx), glutathione reductase (GRd), and $\gamma$-glutamyl-cystein synthase. This special class of antioxidant generates a series of metabolites that are also free radical scavengers when scavenging free radicals [79-83]. In other words, as compared to other antioxidants, melatonin is more effective in preventing damage caused by oxidative stress. Capable of crossing cell membranes and of easily reaching all cell compartments, it is taken up by mitochondria and can maintain mitochondrial homeostasis in different experimental models [78,84-87]. Melatonin increases membrane fluidity, electron transfer chain (ETC) complex activity, ATP production, and mitochondrial membrane potential, while reducing oxidative stress and closing mitochondrial permeability transition pores (MPTPs) [88]. Its important anti-inflammatory effects include expression inhibition of iNOS/i-mtNOS, COX-2, and pro-inflammatory cytokines such as IL-1 $\beta$ or TNF- $\alpha$. Many of these properties are attributed to the inhibition of NF-kB-dependent innate immune pathway activation $[89,90]$, and we recently showed that melatonin blunts NLRP3 inflammasome activation under different experimental conditions [11,91,92]. Table 2 summarizes the biological effects of melatonin.

\subsection{Melatonin in the Oral Cavity}

We recently demonstrated that melatonin is synthesized in oral mucosa, where it is involved in autocrine/paracrine signaling by binding to MT1 (melatonin receptor type 1A), MT2 (melatonin receptor 1B), and ROR $\gamma$ (RAR-related orphan receptor gamma) receptors, thus suggesting that it plays a role in normal oral mucosal physiology [11]. We found that aralkylamine $N$-acetyltransferase (AANAT) and acetylserotonin $O$-methyltransferase (ASMT), the two main enzymes in melatonin synthesis, are expressed in oral mucosa and also in salivary glands. However, melatonin, which is also found in saliva, is believed to passively enter the mucous through the circulatory system in salivary glands (parotid, submaxillary, and sublingual glands) [78,93]. Thus, as the quantity of melatonin entering the oral cavity is proportional to salivary flow, xerostomia, which actually aggravates periodontal status, could be associated with oral pathologies [94]. Together, these data, which are corroborated by the literature, demonstrate that melatonin has important implications for the prevention of oral cavity diseases by limiting tissue damage through free radicals and by stimulating immune responses. Almughrabi et al. demonstrated the relationship between low levels of melatonin in saliva and the increased severity of oral pathologies such as gingivitis, chronic periodontitis, and aggressive periodontitis [95]. The beneficial effects of topical melatonin applications in patients with periodontal diseases, as evidenced by improvements in the gingival index and pocket depth, have been established by Gomez-Moreno et al. [96]. Melatonin has also been proven to be an effective treatment for oral infections such as herpes [94]. Kara et al. showed that it decreases proinflammatory cytokines in gingivitis and periodontitis [97]. Cutando et al. [98] showed that melatonin treatment in patients with diabetes significantly reduced the gingival index, pocket depth, and RANKL (receptor activator of nuclear factor kappa-B ligand) levels, and also increased osteoprotegrin concentrations. Due to its anti-inflammatory and anti-oxidative effects, the severity of gingival and periodontal inflammation was reduced. Other studies have demonstrated that melatonin could be a beneficial therapy after surgical procedures in the oral cavity by preventing inflammatory and infectious complications induced by oxidative stress [99]. Cutando et al. [99] showed that topically applied melatonin in the evacuated sockets following tooth removal reduced oxidative stress and inflammation and accelerated the healing process. Thus, by being directly deposited in the oral cavity, it has the capacity to treat oral disorders and pathologies by reducing inflammatory responses in the gingiva and periodontium [94]. 
Table 2. Melatonin biological effects. Up arrows (increase) whereas, down arrow (decrease).

\begin{tabular}{|c|c|c|}
\hline Molecule, Activity, or Process & Biological Effect of Melatonin & References \\
\hline \multicolumn{3}{|c|}{ Reactive oxygen species } \\
\hline $\mathrm{OH}^{\bullet-}$ (hydroxyl radical) & $\downarrow$ & {$[100]$} \\
\hline $\mathrm{O}_{2}^{\bullet}-$ (oxygen free radical) & $\downarrow$ & {$[100]$} \\
\hline $\mathrm{H}_{2} \mathrm{O}_{2}$ (hydrogen peroxide) & $\downarrow$ & {$[83]$} \\
\hline $\mathrm{LO}^{\bullet}-, \mathrm{LOO}^{\bullet}-$ (alkoxyl, peroxyl radicals) & $\downarrow$ & [101] \\
\hline NO (nitric oxide) & $\downarrow$ & [83] \\
\hline $\mathrm{ONOO}^{\bullet}{ }^{-}$(peroxynitrite) & $\downarrow$ & [102] \\
\hline \multicolumn{3}{|c|}{ DNA lesions } \\
\hline 8-hydroxyguanine & $\downarrow$ & {$[103,104]$} \\
\hline 8-oxo-2'-deoxyguanosine & $\downarrow$ & {$[103,104]$} \\
\hline \multicolumn{3}{|c|}{ Inflammation } \\
\hline NF-kB (nuclear factor- $k B$ ) & $\downarrow$ & {$[11,91,92]$} \\
\hline COX-2 (cyclooxygenase-2) & $\downarrow$ & [105] \\
\hline Interleukins & $\downarrow$ & {$[106,107]$} \\
\hline NLRP3 & $\downarrow$ & {$[11,91,92]$} \\
\hline TNF- $\alpha$ (tumor necrosis factor- $\alpha)$ & $\downarrow$ & {$[106,107]$} \\
\hline iNOS (inducible nitric oxide synthase) & $\downarrow$ & {$[106,107]$} \\
\hline MPO (myeloperoxidase) & $\downarrow$ & [108] \\
\hline \multicolumn{3}{|c|}{ Cell death } \\
\hline p53 & $\downarrow$ & [109] \\
\hline Caspases $($ Cas-3, 8, 9, ... ) & $\downarrow$ & {$[11,83]$} \\
\hline cytochrome $c$ (in cytosol) & $\downarrow$ & [109] \\
\hline Bcl-2, Bcl-xL (anti-apoptosis) & $\downarrow$ & {$[11,83]$} \\
\hline Bax, Bak (pro-apoptosis) & $\downarrow$ & {$[11,83]$} \\
\hline \multicolumn{3}{|c|}{ Autophagy } \\
\hline Beclin-1, Atg3, Atg12, ... . (pro-autophagy) & $\downarrow$ & {$[110,111]$} \\
\hline mTOR (pro-autophagy) & $\downarrow$ & {$[110,111]$} \\
\hline PI3K/Akt (anti-autophagy) & $\uparrow$ & {$[110,111]$} \\
\hline \multicolumn{3}{|c|}{ Antioxidative defense system } \\
\hline GSH (glutathione) & $\uparrow$ & {$[11,83]$} \\
\hline SOD (superoxide dismutase) & $\uparrow$ & {$[11,83]$} \\
\hline CAT (catalase) & $\uparrow$ & {$[11,83]$} \\
\hline GPx (glutathione peroxidase) & $\uparrow$ & {$[11,83]$} \\
\hline GRd (glutathione reducatse) & $\uparrow$ & {$[11,83]$} \\
\hline glutathione synthetase & $\uparrow$ & {$[112]$} \\
\hline$\gamma$-glutamyl-cysteinyl synthetase & $\uparrow$ & [112] \\
\hline
\end{tabular}

\subsection{Melatonin as a Radio-Protective Agent}

For many years, the radio-protective effects of melatonin have been observed in different experimental models as well as organs and tissues. Tan et al. [113] were the first to report its ability to protect against electromagnetic radiation emitted by ultraviolet light, with subsequent studies reporting its effectiveness in protecting against ionizing radiation. Vijayalaxmi et al., who carried out a series of experiments to study the radio-protective effects of melatonin in vitro and in vivo, showed that melatonin guarded against $\gamma$ radiation-induced cell damage in blood lymphocytes [114-117]. Other authors have reported that it prevents hemolysis in irradiated human red blood cells [118]. Pretreatment with melatonin guards erythrocytes, granulocytes, macrophages, megakaryotes, and $\mathrm{T}$ cells against radiation-induced cellular injury and also inhibits splenocyte apoptosis in whole-body irradiated mice [119]. It also prevents radiation-induced damage in retinal cells [120], thymocytes [121], and bone-marrow cells in mice [122]. Several in vivo studies reveal that it increases the survival rate 
of animals exposed to radiation. Pre-treatment with $250 \mathrm{mg} / \mathrm{kg}$ melatonin raised the survival rate of lethally whole-body irradiated (9.5 Gy) mice [123] to approximately $43 \%$ and to $85 \%$ at a dose of $8.15 \mathrm{~Gy}$ [124]. Iwata et al. demonstrated that pre-treatment with intraperitoneally administered melatonin at a dosage of $150 \mathrm{mg} / \mathrm{kg}$ showed a survival rate of around $100 \%$ for mice following a radiation dose of 7.5 Gy [125], with an amelioration in radiation-induced injury in radio-sensitive organs such as bone marrow, spleen, and gastrointestine [126]. In all these experiments, melatonin was observed to protect against radiation-induced genotoxicity in both the somatic and germ cells of mice. Its radio-protective impact was also demonstrated in the testis and ovary of irradiated rodents [127-130]. Melatonin also plays an important protective role against radiation-induced damage to the thyroid gland [131] and the small intestine [132], which is one of the most radio-sensitive organs, resulting in inflammation-induced radiation enteritis. Its administration prior to irradiation guards against intestinal damage caused by X-rays [133]. It prevents mucosal intestinal damage caused by radiotherapy by countering structural changes in the small intestine (as evidenced by the villous pattern of the intestinal mucosa) [134] and also inhibits gut bacterial translocation to the spleen, liver, and kidney [119].

The mechanisms involved in melatonin as a radioprotective agent have been attributed to its antioxidant properties, which reduce radiation-induced DNA damage and lipid peroxidation, and to its protection of the immune system by reducing apoptosis through the inhibition of p53 and Bax and by enhancing anti-apoptotic protein Bcl-2 [119,126,135]; it is also involved in repairing lesions in cellular DNA [136].

In patients, the administration of melatonin resulted in amelioration of hypotension, myelotoxicity, and lymphocytopenia associated with radiotherapy [137]. Therefore, its use as a prophylactic agent could reduce morbidity and limit radiation-induced injury in cancer patients under radiotherapy $[119,135]$.

\subsection{The Use of Melatonin in the Prevention of Radiation-Induced Mucositis}

Together, given the data summarized in this review, highlighting its anti-inflammatory and antioxidant function in the oral cavity and its potential effectiveness in protecting against ionizing radiation, melatonin could, in our view, play a beneficial role in the prevention of mucositis. We demonstrated that the application of a melatonin gel to oral mucosa prevented oral mucositis in irradiated rats [11]. For these experiments, the tongue was irradiated under anesthesia $(1 \mathrm{~mL}$ equithesin/ $\mathrm{kg}$ body weight, IP) at 7.5 Gy/day for 5 consecutive days. Melatonin gel or vehicle was applied in the oral cavity $48 \mathrm{~h}$ before each irradiation dose and up to 14 days after the last irradiation exposure. Melatonin gel was applied three times a day in the intraoral regions using a plastic Pasteur pipette. The gel containing 3\% melatonin was dissolved in $0.3 \%$ ethanol:Pluronic F-127. The gel was made in our laboratory and it is under patent. Previously, we performed a dose-response study and the maximal therapeutic effect was obtained with $3 \%$ melatonin gel. Therefore, in the group that received melatonin gel, the total melatonin dose was $45 \mathrm{mg}$ /day for 21 days. The purpose of this study was to investigate the pathophysiology of oral mucositis and how melatonin can prevent its development. We observed that melatonin gel is capable of preventing mucosal disruption and the emergence of ulcers. Furthermore, it can prevent the loss of proliferative progenitor stem cells caused by radiation and enhance their capacity to repopulate the tissue. In addition, ionizing radiation exposure causes oxidative damage to DNA, which arrests the cell cycle, inhibits growth, and increases cell death [119]. Thus, the protection of cellular DNA is of utmost importance in reducing radiation-induced cellular perturbation and also in the proliferation/differentiation of normal cells. Melatonin treatment significantly reduces radiation-induced DNA degradation. Therefore, given the high dependence of both epidermis and mucosal epithelia on resident self-renewing stem cells, the therapeutic interventions using melatonin described above, which can reduce the deleterious effects of radiation on normal epithelial stem cells, could have a considerable impact on the quality of life of cancer patients. 
On the other hand, it is well known that irradiation inhibits the activity of mitochondrial ETC complexes which enhances electron leakage and subsequent superoxide anion $\left(\mathrm{O}_{2}{ }^{\bullet}{ }^{-}\right)$generation, leading to persistent oxidative stress, responsible, at least partially, for radiation-induced cell death in normal human fibroblast cells [138]. Given the induction of mitochondrial dysfunction by ionizing radiation, we assessed whether mitochondrial damage is involved in radiation-induced mucositis. We also determined whether the known improvement by melatonin of mitochondrial function could protect oral mucosa against deleterious radiation effects. In our experiments, we found that the application of melatonin gel decreased the radiation-induced oxidation responses of mitochondria. We also observed that the protective effect of melatonin was mediated by the increased expression and activity of mitochondrial antioxidant enzymes such as GRd. This reduced the mitochondrial GSSG/GSH (oxidized glutathione/reduced glutathione) ratio and restored mitochondrial GSH homeostasis [84], thus enabling mitochondria to recover from post-radiation oxidative stress. This is in line with the finding that melatonin gel increases ETC protein expression and activity and also expands citrate synthase activity, reflecting the increase in mitochondrial mass, resulting in a full recovery of their bio-energetic capacity and the prevention of cell death. These findings suggest that the reduction in mitochondrial damage by melatonin by preserving mitochondrial structure and function may underlie its efficacy in preventing mucositis. The prevention of mitochondrial damage in irradiated oral mucosa may therefore constitute one of the mechanisms by which melatonin protects against cell death. Interestingly, we found that it inhibits mitochondrial-dependent apoptosis by decreasing the Bax/Bcl-2 ratio. It also significantly inhibits $\mathrm{p} 53$ and Bax protein expression, while anti-apoptotic Bcl-2 protein expression increases considerably. Consequently, at least part of its radio-protective capacity could depend on the inhibitory action of p53-related signaling proteins, which prevents the opening of MPTPs and thus blocks the release of cytochrome $c$ to the cytosol. In this regard, radiation induces MPTPs to open up and mitochondrial DNA (mtDNA) to translocate to the cytosol. In addition to ROS released from damaged mitochondria to the cytosol, mtDNA promotes the assembly of NLRP3 inflammasome, a multiprotein complex which activates caspase-1 [139]. Once activated, caspase-1 converts NF-kB-dependent pro-inflammatory cytokines, including pro-IL-1 $\beta$, into a mature form. Thus, the activation of both NLRP3 inflammasome and NF-KB innate immunity pathways leads to the overproduction of IL-1 $\beta$, TNF- $\alpha$, and other pro-inflammatory mediators [139]. This double-stranded, innate immune response by the NF- $\mathrm{KB}$ and NLRP3 inflammasome pathways could explain the difficulty of finding an effective anti-mucositis therapy. Furthermore, the presence of impaired mitochondria underlying these inflammatory responses makes the search for a specific treatment more difficult. Our results highlight the importance of scavenging ROS and the protection of mitochondria from irradiation in order to suppress inflammasome activation and consequently the development of oral mucositis. This would, in turn, help to explain the therapeutic benefits of melatonin gel in combating oral mucositis (Figure 2).

On the other hand, as discussed above, epithelial crypts in the intestinal region contain the highest proliferating cells [140], which are extremely sensitive to ionizing radiation [141]. Recent studies have reported that, even when the intestine is outside the irradiation field, radiation-induced damage to healthy intestine tissue is a common side-effect of out-of-field or scattered radiation. This could explain why typical signs of mucositis were detected in the small intestine following tongue irradiation. Histological analysis revealed crypt loss, lower villi numbers, and shorter lengths in the gastrointestinal region, leading to the conclusion that radiation enteropathy prevention requires protection of the small intestine. Melatonin gel treatment in the mouth, which was observed to reduce intestinal morpho-pathological changes [19], is therefore also associated with improved preservation of both small intestinal and oral mucosa.

In addition, a number of studies have shown that melatonin contains remarkable oncostatic properties. Its antiproliferative properties have been demonstrated in an extensive variety of tumors, including breast, endometrial, prostate, colon, and ovarian cancers as well as choriocarcinoma, melanoma, neuroblastoma, and osteosarcoma among others [142,143]. Its oncostatic mechanisms 
are associated with several hallmarks of cancer. Its anticancer action directly inhibits the proliferation and growth of tumor cells [144]. Melatonin protects normal cells from apoptosis, while, at the same time, promoting apoptotic cell death in several types of cancer cells [145]. Its immune-modulatory anticancer action also augments antitumor immune response [146]. Additionally, melatonin has an important metabolic effect, which decreases glucose uptake by cancer cells [147] and inhibits tumor growth through the suppression of the uptake of linoleic acid and its metabolism by the tumor to the mitogenic molecule 13-HODE [148]. Its anti-angiogenic and anti-metastatic properties have also been reported in numerous studies [149-151]. Given its capacity to increase the efficacy of anticancer drugs, these data show that melatonin can be used not only to treat mucositis due to the absence of adverse side effects, but also can be used in cancer co-treatment programs.

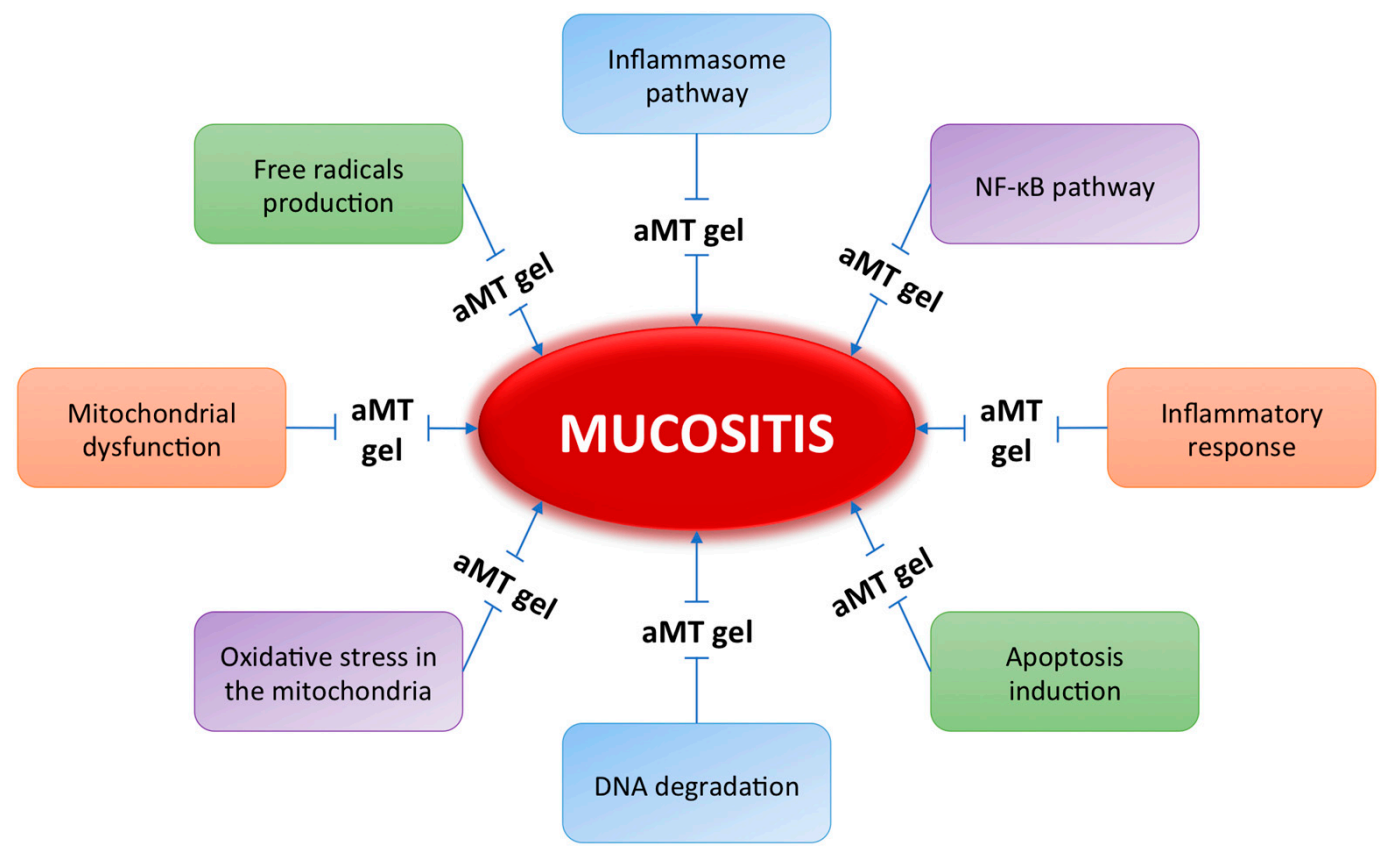

Figure 2. Molecular pathways of melatonin gel for preventing oral mucosa.

\section{Conclusions}

In summary, oral mucositis is a clinically important, deleterious consequence of chemo and radiotherapy, for which no effective treatment has been found to date. Mucositis lesions can be painful, affect nutrition and quality of life, and have a significant economic impact. The pathogenesis of oral mucositis is multifactorial and complex, and not all mucositis can be prevented. Once mucositis has developed, therapy should focus on supportive care, which aims to maintain hydration, provide appropriate caloric intake through enteral or parenteral nutritional support, relieve pain, and to prevent infection. This review discusses current clinical practices in the management of oral mucositis and emphasizes that no standard therapeutic approach has been developed for patients suffering from oral mucositis. Thus, basic, translational, and clinical research into how to prevent and treat oral and gastrointestinal mucositis continues. Our findings, showing that melatonin reduces irradiation toxicity and prevents treatment-induced mucositis, indicate that, with its oncostatic and cytoprotective properties, it constitutes an innovative, adjuvant strategy in the treatment of cancer. We demonstrated that treatment with melatonin gel protects rats from post-radiation oral mucositis, prevents duodenal inflammation and necrosis, and restores mucosal endogenous melatonin levels in irradiated animals. A clinical trial of this gel, which is under patent, is currently underway to test for the prevention of oral mucositis in head and neck cancer patients. 
Acknowledgments: Part of this study was partially funded by the following grants: SAF2009-14037 from the Spanish Ministry of Economy and Competitivity (MINECO), CB/10/00238 from the Carlos III Health Institute, GREIB.PT_2010_04 from the CEIBiotic Program of the University of Granada, Spain, and CTS-101 from the Innovation, Science, and Business Council, Junta de Andalucía, Spain. Finally, we wish to thank Michael O'Shea for proofreading the paper.

Conflicts of Interest: The authors declare no conflict of interest.

$\begin{array}{ll}\text { Abbreviations } \\ \text { ApoE } & \text { Apolipoprotein E } \\ \text { COX-2 } & \text { Cyclooxygenase-2 } \\ \text { CTCAE } & \text { Common terminology criteria for adverse events } \\ \text { EGF } & \text { Epidermal growth factor } \\ \text { G-CSF } & \text { Granulocyte colony-stimulating factor } \\ \text { GIT } & \text { Gastrointestinal tract } \\ \text { GM-CSF } & \text { Granulocyte-macrophage colony stimulating factor } \\ \text { IL-1 } & \text { Interleukin-1 } \\ \text { MAPK } & \text { Mitogen-activated protein kinase } \\ \text { MMP } & \text { Matrix metalloproteinase } \\ \text { mTOR } & \text { Mammalian target of rapamycin } \\ \text { NAC } & \text { N-acetyl cysteine } \\ \text { NCI } & \text { National Cancer Institute } \\ \text { NF- } \mathrm{B} \text { N } & \text { Nuclear factor- } \mathrm{kB} \\ \text { NLRP3 } & \text { NACHT, LRR, and PYD domains-containing protein 3 } \\ \text { NSAID } & \text { Non-steroidal anti-inflammatory drug } \\ \text { PARs } & \text { Protease-activated receptors } \\ \text { PGE } & \text { Prostaglandin E } \\ \text { PLAG } & \text { 1-palmitoyl-2-linoleoyl-3-acetyl-rac-glycerol } \\ \text { rhEGF } & \text { Recombinant human EGF } \\ \text { ROS } & \text { Reactive oxygen species } \\ \text { SAP } & \text { Serum amyloid-P } \\ \text { Smad7 } & \text { Mothers against decapentaplegic homolog 7 } \\ \text { TCM } & \text { Traditional Chinese medicine } \\ \text { TGF- } \beta & \text { Transforming growth factor- } \beta \\ \text { TNF- } \alpha & \text { Tumor necrosis factor- } \alpha \\ & \end{array}$

\section{References}

1. Trotti, A.; Bellm, L.A.; Epstein, J.B.; Frame, D.; Fuchs, H.J.; Gwede, C.K.; Komaroff, E.; Nalysnyk, L.; Zilberberg, M.D. Mucositis incidence, severity and associated outcomes in patients with head and neck cancer receiving radiotherapy with or without chemotherapy: A systematic literature review. Radiother. Oncol. 2003, 66, 253-262. [CrossRef]

2. Itoh, Y.; Kubota, S.; Kawamura, M.; Nomoto, Y.; Murao, T.; Yamakawa, K.; Ishihara, S.; Hirasawa, N.; Asano, A.; Yanagawa, S.; et al. A multicenter survey of stage T1 glottic cancer treated with radiotherapy delivered in 2.25-Gy fractions in clinical practice: An initial 5-year analysis. Nagoya J. Med. Sci. 2016, 78, 399-406. [PubMed]

3. Epstein, J.B.; Schubert, M.M. Managing pain in mucositis. Semin. Oncol. Nurs. 2004, 20, 30-37. [CrossRef] [PubMed]

4. Sonis, S.T. Oral mucositis in head and neck cancer: Risk, biology, and management. Am. Soc. Clin. Oncol. Educ. Book 2013. [CrossRef] [PubMed]

5. Campos, M.I.; Campos, C.N.; Aarestrup, F.M.; Aarestrup, B.J. Oral mucositis in cancer treatment: Natural history, prevention and treatment. Mol. Clin. Oncol. 2014, 2, 337-340. [PubMed]

6. Kyriakopoulos, C.E.; Braden, A.M.; Kolesar, J.M.; Eickhoff, J.C.; Bailey, H.H.; Heideman, J.; Liu, G.; Wisinski, K.B. A phase I study of tivantinib in combination with temsirolimus in patients with advanced solid tumors. Investig. New Drugs 2016. [CrossRef] [PubMed] 
7. Harris, D.J. Cancer treatment-induced mucositis pain: Strategies for assessment and management. Ther. Clin. Risk Manag. 2006, 2, 251-258. [CrossRef] [PubMed]

8. Dorr, W. Modulation of repopulation processes in oral mucosa: Experimental results. Int. J. Radiat. Biol. 2003, 79, 531-537. [CrossRef] [PubMed]

9. Sonis, S.T. Oral mucositis in cancer therapy. J. Support. Oncol. 2004, 2, 3-8. [PubMed]

10. Lee, C.S.; Ryan, E.J.; Doherty, G.A. Gastro-intestinal toxicity of chemotherapeutics in colorectal cancer: The role of inflammation. World J. Gastroenterol. 2014, 20, 3751-3761. [CrossRef] [PubMed]

11. Ortiz, F.; Acuna-Castroviejo, D.; Doerrier, C.; Dayoub, J.C.; Lopez, L.C.; Venegas, C.; Garcia, J.A.; Lopez, A.; Volt, H.; Luna-Sanchez, M.; et al. Melatonin blunts the mitochondrial/NLRP3 connection and protects against radiation-induced oral mucositis. J. Pineal Res. 2015, 58, 34-49. [CrossRef] [PubMed]

12. Escames, G.; Lopez, L.C.; Garcia, J.A.; Garcia-Corzo, L.; Ortiz, F.; Acuna-Castroviejo, D. Mitochondrial DNA and inflammatory diseases. Hum. Genet. 2012, 131, 161-173. [CrossRef] [PubMed]

13. Villa, A.; Sonis, S.T. Mucositis: Pathobiology and management. Curr. Opin. Oncol. 2015, 27, $159-164$. [CrossRef] [PubMed]

14. Volpato, L.E.R.; Silva, T.C.; Oliveira, T.M.; Sakai, V.T.; Machado, M.A.A.M. Radiation therapy and chemotherapy-induced oral mucositis. Rev. Bras. Otorrinolaringol. 2007, 73, 562-568. [CrossRef]

15. Khaw, A.; Logan, R.; Keefe, D.; Bartold, M. Radiation-induced oral mucositis and periodontitis-Proposal for an inter-relationship. Oral Dis. 2014, 20, e7-e18. [CrossRef] [PubMed]

16. Keefe, D.M.; Brealey, J.; Goland, G.J.; Cummins, A.G. Chemotherapy for cancer causes apoptosis that precedes hypoplasia in crypts of the small intestine in humans. Gut 2000, 47, 632-637. [CrossRef] [PubMed]

17. Bowen, J.M.; Keefe, D.M. New pathways for alimentary mucositis. J. Oncol. 2008, 2008, 907892. [CrossRef] [PubMed]

18. Cameron, S.; Schwartz, A.; Sultan, S.; Schaefer, I.M.; Hermann, R.; Rave-Frank, M.; Hess, C.F.; Christiansen, H.; Ramadori, G. Radiation-induced damage in different segments of the rat intestine after external beam irradiation of the liver. Exp. Mol. Pathol. 2012, 92, 243-258. [CrossRef] [PubMed]

19. Fernández-Gil, B.; Abdel Moneim, A.E.; Ortiz, F.; Shen, Y.-Q.; Soto-Mercado, V.; Mendivil-Perez, M.; Librero, A.G.; Acuña-Castroviejo, D.; Molina-Navarro, M.M.; Garcia-Verdugo, J.M.; et al. Melatonin protects rats from radiotherapy-induced gut toxicity. PLoS ONE 2017, 12, e0174474. [CrossRef] [PubMed]

20. Scully, C.; Epstein, J.; Sonis, S. Oral mucositis: A challenging complication of radiotherapy, chemotherapy, and radiochemotherapy: Part 1, pathogenesis and prophylaxis of mucositis. Head Neck 2003, 25, 1057-1070. [CrossRef] [PubMed]

21. Allison, R.R.; Ambrad, A.A.; Arshoun, Y.; Carmel, R.J.; Ciuba, D.F.; Feldman, E.; Finkelstein, S.E.; Gandhavadi, R.; Heron, D.E.; Lane, S.C.; et al. Multi-institutional, randomized, double-blind, placebocontrolled trial to assess the efficacy of a mucoadhesive hydrogel (MuGard) in mitigating oral mucositis symptoms in patients being treated with chemoradiation therapy for cancers of the head and neck. Cancer 2014, 120, 1433-1440. [CrossRef] [PubMed]

22. Quinn, B. Efficacy of a supersaturated calcium phosphate oral rinse for the prevention and treatment of oral mucositis in patients receiving high-dose cancer therapy: A review of current data. Eur. J. Cancer Care 2013, 22, 564-579. [CrossRef] [PubMed]

23. Buchsel, P.C. Polyvinylpyrrolidone-sodium hyaluronate gel (Gelclair ${ }^{\circledR}$ ): A bioadherent oral gel for the treatment of oral mucositis and other painful oral lesions. Expert Opin. Drug Metab. Toxicol. 2008, 4, 1449-1454. [CrossRef] [PubMed]

24. Raphael, M.F.; den Boer, A.M.; Kollen, W.J.; Mekelenkamp, H.; Abbink, F.C.; Kaspers, G.J.; Zomer-Kooijker, K.; Molmans, B.H.; Tissing, W.J. Caphosol, a therapeutic option in case of cancer therapy-induced oral mucositis in children? Results from a prospective multicenter double blind randomized controlled trial. Support. Care Cancer 2014, 22, 3-6. [CrossRef] [PubMed]

25. Lalla, R.V.; Sonis, S.T.; Peterson, D.E. Management of oral mucositis in patients who have cancer. Dent. Clin. N. Am. 2008, 52, 61-77. [CrossRef] [PubMed]

26. Leenstra, J.L.; Miller, R.C.; Qin, R.; Martenson, J.A.; Dornfeld, K.J.; Bearden, J.D.; Puri, D.R.; Stella, P.J.; Mazurczak, M.A.; Klish, M.D.; et al. Doxepin rinse versus placebo in the treatment of acute oral mucositis pain in patients receiving head and neck radiotherapy with or without chemotherapy: A phase III, randomized, double-blind trial (NCCTG-N09C6 [Alliance]). J. Clin. Oncol. 2014, 32, 1571-1577. [CrossRef] [PubMed] 
27. Rubenstein, E.B.; Peterson, D.E.; Schubert, M.; Keefe, D.; McGuire, D.; Epstein, J.; Elting, L.S.; Fox, P.C.; Cooksley, C.; Sonis, S.T. Clinical practice guidelines for the prevention and treatment of cancer therapy-induced oral and gastrointestinal mucositis. Cancer 2004, 100, 2026-2046. [CrossRef] [PubMed]

28. Xing, S.Z.; Zhang, Y. Efficacy and safety of transdermal fentanyl for the treatment of oral mucositis pain caused by chemoradiotherapy in patients with esophageal squamous cell carcinoma. Support. Care Cancer 2014, 23, 753-759. [CrossRef] [PubMed]

29. Gotzsche, P.C.; Johansen, H.K. Nystatin prophylaxis and treatment in severely immunodepressed patients. Cochrane Database Syst. Rev. 2014, 9, CD002033.

30. Silva, F.C.; Marto, J.M.; Salgado, A.; Machado, P.; Silva, A.N.; Almeida, A.J. Nystatin and lidocaine pastilles for the local treatment of oral mucositis. Pharm. Dev. Technol. 2017, 22, 266-274. [CrossRef] [PubMed]

31. Bey, A.; Ahmed, S.S.; Hussain, B.; Devi, S.; Hashmi, S.H. Prevention and management of antineoplastic therapy induced oral mucositis. Natl. J. Maxillofac. Surg. 2010, 1, 127-134. [PubMed]

32. Epstein, J.B.; Vickars, L.; Spinelli, J.; Reece, D. Efficacy of chlorhexidine and nystatin rinses in prevention of oral complications in leukemia and bone marrow transplantation. Oral Surg. Oral Med. Oral Pathol. 1992, 73, 682-689. [CrossRef]

33. Cardona, A.; Balouch, A.; Abdul, M.M.; Sedghizadeh, P.P.; Enciso, R. Efficacy of chlorhexidine for the prevention and treatment of oral mucositis in cancer patients: A systematic review with meta-analyses. J. Oral Pathol. Med. 2017, 23, 753-759. [CrossRef] [PubMed]

34. Migliorati, C.A.; Oberle-Edwards, L.; Schubert, M. The role of alternative and natural agents, cryotherapy, and/or laser for management of alimentary mucositis. Support. Care Cancer 2006, 14, 533-540. [CrossRef] [PubMed]

35. Peterson, D.E.; Ohrn, K.; Bowen, J.; Fliedner, M.; Lees, J.; Loprinzi, C.; Mori, T.; Osaguona, A.; Weikel, D.S.; Elad, S.; et al. Systematic review of oral cryotherapy for management of oral mucositis caused by cancer therapy. Support. Care Cancer 2013, 21, 327-332. [CrossRef] [PubMed]

36. Tayyem, A.Q. Cryotherapy effect on oral mucositis severity among recipients of bone marrow transplantation: A literature review. Clin. J. Oncol. Nurs. 2014, 18, E84-E87. [CrossRef] [PubMed]

37. Riley, P.; McCabe, M.G.; Glenny, A. Oral cryotherapy for preventing oral mucositis in patients receiving cancer treatment. JAMA Oncol. 2016, 2, 1365-1366. [CrossRef] [PubMed]

38. Kadakia, K.C.; Rozell, S.A.; Butala, A.A.; Loprinzi, C.L. Supportive cryotherapy: A review from head to toe. J. Pain Symptom Manag. 2014, 47, 1100-1115. [CrossRef] [PubMed]

39. Nicolatou-Galitis, O.; Sarri, T.; Bowen, J.; di Palma, M.; Kouloulias, V.E.; Niscola, P.; Riesenbeck, D.; Stokman, M.; Tissing, W.; Yeoh, E.; et al. Systematic review of amifostine for the management of oral mucositis in cancer patients. Support. Care Cancer 2013, 21, 357-364. [CrossRef] [PubMed]

40. Moslehi, A.; Taghizadeh-Ghehi, M.; Gholami, K.; Hadjibabaie, M.; Jahangard-Rafsanjani, Z.; Sarayani, A.; Javadi, M.; Esfandbod, M.; Ghavamzadeh, A. N-acetyl cysteine for prevention of oral mucositis in hematopoietic sct: A double-blind, randomized, placebo-controlled trial. Bone Marrow Transplant. 2014, 49, 818-823. [CrossRef] [PubMed]

41. Spielberger, R.; Stiff, P.; Bensinger, W.; Gentile, T.; Weisdorf, D.; Kewalramani, T.; Shea, T.; Yanovich, S.; Hansen, K.; Noga, S.; et al. Palifermin for oral mucositis after intensive therapy for hematologic cancers. N. Engl. J. Med. 2004, 351, 2590-2598. [CrossRef] [PubMed]

42. Vitale, K.M.; Violago, L.; Cofnas, P.; Bishop, J.; Jin, Z.; Bhatia, M.; Kung, A.L.; George, D.; Garvin, J.; Satwani, P. Impact of palifermin on incidence of oral mucositis and healthcare utilization in children undergoing autologous hematopoietic stem cell transplantation for malignant diseases. Pediatr. Transplant. 2014, 18, 211-216. [CrossRef] [PubMed]

43. Yuan, A.; Sonis, S. Emerging therapies for the prevention and treatment of oral mucositis. Expert Opin. Emerg. Drugs 2014, 19, 343-351. [CrossRef] [PubMed]

44. Han, G.; Bian, L.; Li, F.; Cotrim, A.; Wang, D.; Lu, J.; Deng, Y.; Bird, G.; Sowers, A.; Mitchell, J.B.; et al. Preventive and therapeutic effects of Smad7 on radiation-induced oral mucositis. Nat. Med. 2013, 19, 421-428. [CrossRef] [PubMed]

45. He, W.; Li, A.G.; Wang, D.; Han, S.; Zheng, B.; Goumans, M.J.; Ten Dijke, P.; Wang, X.J. Overexpression of Smad7 results in severe pathological alterations in multiple epithelial tissues. EMBO J. 2002, 21, 2580-2590. [CrossRef] [PubMed] 
46. Nicolatou-Galitis, O.; Sarri, T.; Bowen, J.; di Palma, M.; Kouloulias, V.E.; Niscola, P.; Riesenbeck, D.; Stokman, M.; Tissing, W.; Yeoh, E.; et al. Systematic review of anti-inflammatory agents for the management of oral mucositis in cancer patients. Support. Care Cancer 2013, 21, 3179-3189. [CrossRef] [PubMed]

47. Labar, B.; Mrsic, M.; Pavletic, Z.; Bogdanic, V.; Nemet, D.; Aurer, I.; Radman, I.; Filipovic-Grcic, N.; Sertic, D.; Kalenic, S.; et al. Prostaglandin $\mathrm{E}_{2}$ for prophylaxis of oral mucositis following BMT. Bone Marrow Transplant. 1993, 11, 379-382. [PubMed]

48. Kostler, W.J.; Hejna, M.; Wenzel, C.; Zielinski, C.C. Oral mucositis complicating chemotherapy and/or radiotherapy: Options for prevention and treatment. CA Cancer J. Clin. 2001, 51, 290-315. [CrossRef] [PubMed]

49. Coeffier, M.; Marion, R.; Leplingard, A.; Lerebours, E.; Ducrotte, P.; Dechelotte, P. Glutamine decreases interleukin-8 and interleukin-6 but not nitric oxide and prostaglandins $\mathrm{E}_{2}$ production by human gut in vitro. Cytokine 2002, 18, 92-97. [CrossRef] [PubMed]

50. Evans, M.E.; Jones, D.P.; Ziegler, T.R. Glutamine prevents cytokine-induced apoptosis in human colonic epithelial cells. J. Nutr. 2003, 133, 3065-3071. [PubMed]

51. Anderson, P.M.; Ramsay, N.K.; Shu, X.O.; Rydholm, N.; Rogosheske, J.; Nicklow, R.; Weisdorf, D.J.; Skubitz, K.M. Effect of low-dose oral glutamine on painful stomatitis during bone marrow transplantation. Bone Marrow Transplant 1998, 22, 339-344. [CrossRef] [PubMed]

52. Jebb, S.A.; Osborne, R.J.; Maughan, T.S.; Mohideen, N.; Mack, P.; Mort, D.; Shelley, M.D.; Elia, M. 5-fluorouracil and folinic acid-induced mucositis: No effect of oral glutamine supplementation. Br. J. Cancer 1994, 70, 732-735. [CrossRef] [PubMed]

53. Touchefeu, Y.; Montassier, E.; Nieman, K.; Gastinne, T.; Potel, G.; Bruley des Varannes, S.; Le Vacon, F.; de la Cochetiere, M.F. Systematic review: The role of the gut microbiota in chemotherapy- or radiation-induced gastrointestinal mucositis-Current evidence and potential clinical applications. Aliment. Pharmacol. Ther. 2014, 40, 409-421. [CrossRef] [PubMed]

54. Ciais, G.; Namer, M.; Schneider, M.; Demard, F.; Pourreau-Schneider, N.; Martin, P.M.; Soudry, M.; Franquin, J.C.; Zattara, H. Laser therapy in the prevention and treatment of mucositis caused by anticancer chemotherapy. Bull. Cancer 1992, 79, 183-191. [PubMed]

55. Barasch, A.; Peterson, D.E.; Tanzer, J.M.; D’Ambrosio, J.A.; Nuki, K.; Schubert, M.M.; Franquin, J.C.; Clive, J.; Tutschka, P. Helium-neon laser effects on conditioning-induced oral mucositis in bone marrow transplantation patients. Cancer 1995, 76, 2550-2556. [CrossRef]

56. Cowen, D.; Tardieu, C.; Schubert, M.; Peterson, D.; Resbeut, M.; Faucher, C.; Franquin, J.C. Low energy helium-neon laser in the prevention of oral mucositis in patients undergoing bone marrow transplant: Results of a double blind randomized trial. Int. J. Radiat. Oncol. Biol. Phys. 1997, 38, 697-703. [CrossRef]

57. Oberoi, S.; Zamperlini-Netto, G.; Beyene, J.; Treister, N.S.; Sung, L. Effect of prophylactic low level laser therapy on oral mucositis: A systematic review and meta-analysis. PLoS ONE 2014, 9, e107418. [CrossRef] [PubMed]

58. Alvarino-Martin, C.; Sarrion-Perez, M.G. Prevention and treatment of oral mucositis in patients receiving chemotherapy. J. Clin. Exp. Dent. 2014, 6, e74-e80. [CrossRef] [PubMed]

59. Allan, E.; Barney, C.; Baum, S.; Kessling, T.; Diavolitsis, V.M.; Blakaj, D.; Grecula, J.C.; Rocco, J.W.; van Putten, M.; Bhatt, A.D. Low-level laser therapy and laser debridement for management of oral mucositis in patients with head and neck cancer receiving chemotherapy and radiation. Int. J. Radiat. Oncol. Biol. Phys. 2016, 94, 883. [CrossRef]

60. Sonis, S.T.; Hashemi, S.; Epstein, J.B.; Nair, R.G.; Raber-Durlacher, J.E. Could the biological robustness of low level laser therapy (photobiomodulation) impact its use in the management of mucositis in head and neck cancer patients. Oral Oncol. 2016, 54, 7-14. [CrossRef] [PubMed]

61. Yeung, C.Y.; Chan, W.T.; Jiang, C.B.; Cheng, M.L.; Liu, C.Y.; Chang, S.W.; Chiang Chiau, J.S.; Lee, H.C. Amelioration of chemotherapy-induced intestinal mucositis by orally administered probiotics in a mouse model. PLoS ONE 2015, 10, e0138746. [CrossRef] [PubMed]

62. Osterlund, P.; Ruotsalainen, T.; Korpela, R.; Saxelin, M.; Ollus, A.; Valta, P.; Kouri, M.; Elomaa, I.; Joensuu, H. Lactobacillus supplementation for diarrhoea related to chemotherapy of colorectal cancer: A randomised study. Br. J. Cancer 2007, 97, 1028-1034. [CrossRef] [PubMed] 
63. Delia, P.; Sansotta, G.; Donato, V.; Messina, G.; Frosina, P.; Pergolizzi, S.; de Renzis, C.; Famularo, G. Prevention of radiation-induced diarrhea with the use of VSL\#3, a new high-potency probiotic preparation. Am. J. Gastroenterol. 2002, 97, 2150-2152. [PubMed]

64. Pottel, L.; Lycke, M.; Boterberg, T.; Pottel, H.; Goethals, L.; Duprez, F.; Maes, A.; Goemaere, S.; Rottey, S.; Foubert, I.; et al. Echium oil is not protective against weight loss in head and neck cancer patients undergoing curative radio(chemo)therapy: A randomised-controlled trial. BMC Complement. Altern. Med. 2014, 14, 382. [CrossRef] [PubMed]

65. Meyer-Hamme, G.; Beckmann, K.; Radtke, J.; Efferth, T.; Greten, H.J.; Rostock, M.; Schroder, S. A survey of chinese medicinal herbal treatment for chemotherapy-induced oral mucositis. Evid. Based Complement. Altern. Med. 2013, 2013, 284959. [CrossRef] [PubMed]

66. Liu, Z.; Xi, J.; Schroder, S.; Wang, W.; Xie, T.; Wang, Z.; Bao, S.; Fei, J. Chimonanthus nitens var. Salicifolius aqueous extract protects against 5-fluorouracil induced gastrointestinal mucositis in a mouse model. Evid. Based Complement. Altern. Med. 2013, 2013, 789263. [CrossRef] [PubMed]

67. Sencer, S.F.; Zhou, T.; Freedman, L.S.; Ives, J.A.; Chen, Z.; Wall, D.; Nieder, M.L.; Grupp, S.A.; Yu, L.C.; Sahdev, I.; et al. Traumeel s in preventing and treating mucositis in young patients undergoing sct: A report of the children's oncology group. Bone Marrow Transplant 2012, 47, 1409-1414. [CrossRef] [PubMed]

68. Braga, F.T.; Santos, A.C.; Bueno, P.C.; Silveira, R.C.; Santos, C.B.; Bastos, J.K.; Carvalho, E.C. Use of chamomilla recutita in the prevention and treatment of oral mucositis in patients undergoing hematopoietic stem cell transplantation: A randomized, controlled, phase ii clinical trial. Cancer Nurs. 2014, 38, 322-329. [CrossRef] [PubMed]

69. Elkerm, Y.; Tawashi, R. Date palm pollen as a preventative intervention in radiation- and chemotherapy-induced oral mucositis: A pilot study. Integr. Cancer Ther. 2014, 13, 468-472. [CrossRef] [PubMed]

70. Fidler, P.; Loprinzi, C.L.; O’Fallon, J.R.; Leitch, J.M.; Lee, J.K.; Hayes, D.L.; Novotny, P.; Clemens-Schutjer, D.; Bartel, J.; Michalak, J.C. Prospective evaluation of a chamomile mouthwash for prevention of 5-FU-induced oral mucositis. Cancer 1996, 77, 522-525. [CrossRef]

71. Oberbaum, M.; Yaniv, I.; Ben-Gal, Y.; Stein, J.; Ben-Zvi, N.; Freedman, L.S.; Branski, D. A randomized, controlled clinical trial of the homeopathic medication TRAUMEEL $\mathrm{s}^{\circledR}$ in the treatment of chemotherapy-induced stomatitis in children undergoing stem cell transplantation. Cancer 2001, 92, 684-690. [CrossRef]

72. Saadeh, C.E. Chemotherapy- and radiotherapy-induced oral mucositis: Review of preventive strategies and treatment. Pharmacotherapy 2005, 25, 540-554. [CrossRef] [PubMed]

73. Hong, J.P.; Lee, S.W.; Song, S.Y.; Ahn, S.D.; Shin, S.S.; Choi, E.K.; Kim, J.H. Recombinant human epidermal growth factor treatment of radiation-induced severe oral mucositis in patients with head and neck malignancies. Eur. J. Cancer Care 2009, 18, 636-641. [CrossRef] [PubMed]

74. Anderson, P.M.; Schroeder, G.; Skubitz, K.M. Oral glutamine reduces the duration and severity of stomatitis after cytotoxic cancer chemotherapy. Cancer 1998, 83, 1433-1439. [CrossRef]

75. Huang, E.Y.; Leung, S.W.; Wang, C.J.; Chen, H.C.; Sun, L.M.; Fang, F.M.; Yeh, S.A.; Hsu, H.C.; Hsiung, C.Y. Oral glutamine to alleviate radiation-induced oral mucositis: A pilot randomized trial. Int. J. Radiat. Oncol. Biol. Phys. 2000, 46, 535-539. [CrossRef]

76. Lopes, N.N.; Plapler, H.; Chavantes, M.C.; Lalla, R.V.; Yoshimura, E.M.; Alves, M.T. Cyclooxygenase-2 and vascular endothelial growth factor expression in 5-fluorouracil-induced oral mucositis in hamsters: Evaluation of two low-intensity laser protocols. Support. Care Cancer 2009, 17, 1409-1415. [CrossRef] [PubMed]

77. Antunes, H.S.; Herchenhorn, D.; Small, I.A.; Araujo, C.M.; Viegas, C.M.; Cabral, E.; Rampini, M.P.; Rodrigues, P.C.; Silva, T.G.; Ferreira, E.M.; et al. Phase III trial of low-level laser therapy to prevent oral mucositis in head and neck cancer patients treated with concurrent chemoradiation. Radiother. Oncol. 2013, 109, 297-302. [CrossRef] [PubMed]

78. Acuna-Castroviejo, D.; Escames, G.; Venegas, C.; Diaz-Casado, M.E.; Lima-Cabello, E.; Lopez, L.C.; Rosales-Corral, S.; Tan, D.X.; Reiter, R.J. Extrapineal melatonin: Sources, regulation, and potential functions. Cell. Mol. Life Sci. 2014, 71, 2997-3025. [CrossRef] [PubMed]

79. Urata, Y.; Honma, S.; Goto, S.; Todoroki, S.; Iida, T.; Cho, S.; Honma, K.; Kondo, T. Melatonin induces $\gamma$-glutamylcysteine synthetase mediated by activator protein-1 in human vascular endothelial cells. Free Radic. Biol. Med. 1999, 27, 838-847. [CrossRef] 
80. Manchester, L.C.; Coto-Montes, A.; Boga, J.A.; Andersen, L.P.H.; Zhou, Z.; Galano, A.; Vriend, J.; Tan, D.-X.; Reiter, R.J. Melatonin: An ancient molecule that makes oxygen metabolically tolerable. J. Pineal Res. 2015, 59, 403-419. [CrossRef] [PubMed]

81. Zhang, H.-M.; Zhang, Y. Melatonin: A well-documented antioxidant with conditional pro-oxidant actions. J. Pineal Res. 2014, 57, 131-146. [CrossRef] [PubMed]

82. Reiter, R.J.; Mayo, J.C.; Tan, D.-X.; Sainz, R.M.; Alatorre-Jimenez, M.; Qin, L. Melatonin as an antioxidant: Under promises but over delivers. J. Pineal Res. 2016, 61, 253-278. [CrossRef] [PubMed]

83. Abdel Moneim, A.E.; Ortiz, F.; Leonardo-Mendonca, R.C.; Vergano-Villodres, R.; Guerrero-Martinez, J.A.; Lopez, L.C.; Acuna-Castroviejo, D.; Escames, G. Protective effects of melatonin against oxidative damage induced by Egyptian cobra (Naja haje) crude venom in rats. Acta Trop. 2014, 143, 58-65. [CrossRef] [PubMed]

84. Martin, M.; Macias, M.; Escames, G.; Leon, J.; Acuna-Castroviejo, D. Melatonin but not vitamins C and E maintains glutathione homeostasis in t-butyl hydroperoxide-induced mitochondrial oxidative stress. FASEB J. 2000, 14, 1677-1679. [CrossRef] [PubMed]

85. Acuna Castroviejo, D.; Lopez, L.C.; Escames, G.; Lopez, A.; Garcia, J.A.; Reiter, R.J. Melatonin-mitochondria interplay in health and disease. Curr. Top. Med. Chem. 2011, 11, 221-240. [CrossRef] [PubMed]

86. Diaz-Casado, M.E.; Lima, E.; Garcia, J.A.; Doerrier, C.; Aranda, P.; Sayed, R.K.; Guerra-Librero, A.; Escames, G.; Lopez, L.C.; Acuna-Castroviejo, D. Melatonin rescues zebrafish embryos from the parkinsonian phenotype restoring the parkin/PINK1/DJ-1/MUL1 network. J. Pineal Res. 2016, 61, 96-107. [CrossRef] [PubMed]

87. Doerrier, C.; Garcia, J.A.; Volt, H.; Diaz-Casado, M.E.; Luna-Sanchez, M.; Fernandez-Gil, B.; Escames, G.; Lopez, L.C.; Acuna-Castroviejo, D. Permeabilized myocardial fibers as model to detect mitochondrial dysfunction during sepsis and melatonin effects without disruption of mitochondrial network. Mitochondrion 2016, 27, 56-63. [CrossRef] [PubMed]

88. Acuna-Castroviejo, D.; Escames, G.; Rodriguez, M.I.; Lopez, L.C. Melatonin role in the mitochondrial function. Front. Biosci. 2007, 12, 947-963. [CrossRef] [PubMed]

89. Escames, G.; Leon, J.; Macias, M.; Khaldy, H.; Acuna-Castroviejo, D. Melatonin counteracts lipopolysaccharide-induced expression and activity of mitochondrial nitric oxide synthase in rats. FASEB J. 2003, 17, 932-934. [CrossRef] [PubMed]

90. Escames, G.; López, L.C.; Tapias, V.; Utrilla, P.; Reiter, R.J.; Hitos, A.B.; León, J.; Rodríguez, M.I.; Acuña-Castroviejo, D. Melatonin counteracts inducible mitochondrial nitric oxide synthase-dependent mitochondrial dysfunction in skeletal muscle of septic mice. J. Pineal Res. 2006, 40, 71-78. [CrossRef] [PubMed]

91. Garcia, J.A.; Volt, H.; Venegas, C.; Doerrier, C.; Escames, G.; Lopez, L.C.; Acuna-Castroviejo, D. Disruption of the NF-kb/NLRP3 connection by melatonin requires retinoid-related orphan receptor- $\alpha$ and blocks the septic response in mice. FASEB J. 2015, 29, 3863-3875. [CrossRef] [PubMed]

92. Volt, H.; Garcia, J.A.; Doerrier, C.; Diaz-Casado, M.E.; Guerra-Librero, A.; Lopez, L.C.; Escames, G.; Tresguerres, J.A.; Acuna-Castroviejo, D. Same molecule but different expression: Aging and sepsis trigger NLRP3 inflammasome activation, a target of melatonin. J. Pineal Res. 2016, 60, 193-205. [CrossRef] [PubMed]

93. Stehle, J.H.; Saade, A.; Rawashdeh, O.; Ackermann, K.; Jilg, A.; Sebesteny, T.; Maronde, E. A survey of molecular details in the human pineal gland in the light of phylogeny, structure, function and chronobiological diseases. J. Pineal Res. 2011, 51, 17-43. [CrossRef] [PubMed]

94. Reiter, R.J.; Rosales-Corral, S.A.; Liu, X.Y.; Acuna-Castroviejo, D.; Escames, G.; Tan, D.X. Melatonin in the oral cavity: Physiological and pathological implications. J. Periodontal Res. 2015, 50, 9-17. [CrossRef] [PubMed]

95. Almughrabi, O.M.; Marzouk, K.M.; Hasanato, R.M.; Shafik, S.S. Melatonin levels in periodontal health and disease. J. Periodontal Res. 2013, 48, 315-321. [CrossRef] [PubMed]

96. Gomez-Moreno, G.; Guardia, J.; Ferrera, M.J.; Cutando, A.; Reiter, R.J. Melatonin in diseases of the oral cavity. Oral Dis. 2010, 16, 242-247. [CrossRef] [PubMed]

97. Kara, A.; Akman, S.; Ozkanlar, S.; Tozoglu, U.; Kalkan, Y.; Canakci, C.F.; Tozoglu, S. Immune modulatory and antioxidant effects of melatonin in experimental periodontitis in rats. Free Radic. Biol. Med. 2013, 55, 21-26. [CrossRef] [PubMed] 
98. Cutando, A.; Lopez-Valverde, A.; Gomez-de-Diego, R.; Arias-Santiago, S.; de Vicente-Jimenez, J. Effect of gingival application of melatonin on alkaline and acid phosphatase, osteopontin and osteocalcin in patients with diabetes and periodontal disease. Med. Oral Patol. Oral Cir. Bucal 2013, 18, e657-e663. [CrossRef] [PubMed]

99. Cutando, A.; Arana, C.; Gomez-Moreno, G.; Escames, G.; Lopez, A.; Ferrera, M.J.; Reiter, R.J.; Acuna-Castroviejo, D. Local application of melatonin into alveolar sockets of beagle dogs reduces tooth removal-induced oxidative stress. J. Periodontol. 2007, 78, 576-583. [CrossRef] [PubMed]

100. Poeggeler, B.; Thuermann, S.; Dose, A.; Schoenke, M.; Burkhardt, S.; Hardeland, R. Melatonin's unique radical scavenging properties-Roles of its functional substituents as revealed by a comparison with its structural analogs. J. Pineal Res. 2002, 33, 20-30. [CrossRef] [PubMed]

101. Zavodnik, I.B.; Domanski, A.V.; Lapshina, E.A.; Bryszewska, M.; Reiter, R.J. Melatonin directly scavenges free radicals generated in red blood cells and a cell-free system: Chemiluminescence measurements and theoretical calculations. Life Sci. 2006, 79, 391-400. [CrossRef] [PubMed]

102. Blanchard, B.; Pompon, D.; Ducrocq, C. Nitrosation of melatonin by nitric oxide and peroxynitrite. J. Pineal Res. 2000, 29, 184-192. [CrossRef] [PubMed]

103. Qi, W.; Reiter, R.J.; Tan, D.X.; Garcia, J.J.; Manchester, L.C.; Karbownik, M.; Calvo, J.R. Chromium(III)-induced 8-hydroxydeoxyguanosine in DNA and its reduction by antioxidants: Comparative effects of melatonin, ascorbate, and vitamin E. Environ. Health Perspect. 2000, 108, 399-402. [CrossRef] [PubMed]

104. Davanipour, Z.; Poulsen, H.E.; Weimann, A.; Sobel, E. Endogenous melatonin and oxidatively damaged guanine in DNA. BMC Endocr. Disord. 2009, 9, 22. [CrossRef] [PubMed]

105. Woo, S.M.; Min, K.J.; Kwon, T.K. Melatonin-mediated Bim up-regulation and cyclooxygenase-2 (COX-2) down-regulation enhances tunicamycin-induced apoptosis in MDA-MB-231 cells. J. Pineal Res. 2015, 58, 310-320. [CrossRef] [PubMed]

106. Cutando, A.; Montero, J.; Gomez-de Diego, R.; Ferrera, M.J.; Lopez-Valverde, A. Effect of topical application of melatonin on serum levels of C-reactive protein (CRP), interleukin-6 (IL-6) and tumor necrosis factor- $\alpha$ (TNF- $\alpha$ ) in patients with type 1 or type 2 diabetes and periodontal disease. J. Clin. Exp. Dent. 2015, 7, e628-e633. [CrossRef] [PubMed]

107. Brazao, V.; Colato, R.P.; Santello, F.H.; Filipin Mdel, V.; Toldo, M.P.; do Vale, G.T.; Tirapelli, C.R.; do Prado Junior, J.C. Interleukin-17, oxidative stress, and inflammation: Role of melatonin during Trypanosoma cruzi infection. J. Pineal Res. 2015, 59, 488-496. [CrossRef] [PubMed]

108. Shaeib, F.; Khan, S.N.; Ali, I.; Najafi, T.; Maitra, D.; Abdulhamid, I.; Saed, G.M.; Pennathur, S.; Abu-Soud, H.M. Melatonin prevents myeloperoxidase heme destruction and the generation of free iron mediated by self-generated hypochlorous acid. PLoS ONE 2015, 10, e0120737. [CrossRef] [PubMed]

109. Molpeceres, V.; Mauriz, J.L.; García-Mediavilla, M.V.; González, P.; Barrio, J.P.; González-Gallego, J. Melatonin is able to reduce the apoptotic liver changes induced by aging via inhibition of the intrinsic pathway of apoptosis. J. Gerontol. A Biol. Sci. Med. Sci. 2007, 62, 687-695. [CrossRef] [PubMed]

110. Kang, J.W.; Cho, H.I.; Lee, S.M. Melatonin inhibits mTOR-dependent autophagy during liver ischemia/ reperfusion. Cell. Physiol. Biochem. 2014, 33, 23-36. [CrossRef] [PubMed]

111. Yoo, Y.M.; Han, T.Y.; Kim, H.S. Melatonin suppresses autophagy induced by clinostat in preosteoblast MC3T3-E1 cells. Int. J. Mol. Sci. 2016, 17, 526. [CrossRef] [PubMed]

112. Limon-Pacheco, J.H.; Gonsebatt, M.E. The glutathione system and its regulation by neurohormone melatonin in the central nervous system. Cent. Nerv. Syst. Agents Med. Chem. 2010, 10, 287-297. [CrossRef] [PubMed]

113. Tan, D.X.; Chen, L.D.; Poeggeler, B.; Manchester, L.C.; Reiter, R.J. Melatonin: A potent, endogenous hydroxyl radical scavenge. Endocr. J. 1993, 1, 57-60.

114. Vijayalaxmi; Reiter, R.J.; Meltz, M.L. Melatonin protects human blood lymphocytes from radiation-induced chromo some damage. Mutat. Res. 1995, 346, 23-31. [CrossRef]

115. Vijayalaxmi; Reiter, R.J.; Sewerynek, E.; Poeggeler, B.; Leal, B.Z.; Meltz, M.L. Marked reduction of radiation-induced micronuclei in human blood lymphocytes pretreated with melatonin. Radiat. Res. 1995, 143, 102-106. [CrossRef] [PubMed]

116. Vijayalaxmi; Reiter, R.J.; Leal, B.Z.; Meltz, M.L. Effect of melatonin on mitotic and proliferation indices, and sister chromatid exchange in human blood lymphocytes. Mutat. Res. 1996, 351, 187-192. [CrossRef]

117. Vijayalaxmi; Reiter, R.J.; Herman, T.S.; Meltz, M.L. Melatonin reduces $\gamma$ radiation-induced primary DNA damage in human blood lymphocytes. Mutat. Res. 1998, 397, 203-208. [CrossRef] 
118. Tesoriere, L.; D’Arpa, D.; Conti, S.; Giaccone, V.; Pintaudi, A.M.; Livrea, M.A. Melatonin protects human red blood cells from oxidative hemolysis: New insights into the radical-scavenging activity. J. Pineal Res. 1999, 27, 95-105. [CrossRef] [PubMed]

119. Khan, S.; Adhikari, J.S.; Rizvi, M.A.; Chaudhury, N.K. Melatonin attenuates ${ }^{60}$ Co $\gamma$-ray-induced hematopoietic, immunological and gastrointestinal injuries in C57BL/6 male mice. Environ. Toxicol. 2017, 32, 501-518. [CrossRef] [PubMed]

120. Siu, A.W.; Reiter, R.J.; To, C.H. Pineal indoleamines and vitamin E reduce nitric oxide-induced lipid peroxidation in rat retinal homogenates. J. Pineal Res. 1999, 27, 122-128. [CrossRef] [PubMed]

121. Sainz, R.M.; Mayo, J.C.; Uria, H.; Kotler, M.; Antolin, I.; Rodriguez, C.; Menendez-Pelaez, A. The pineal neurohormone melatonin prevents in vivo and in vitro apoptosis in thymocytes. J. Pineal Res. 1995, 19, 178-188. [CrossRef] [PubMed]

122. Maestroni, G.J.; Covacci, V.; Conti, A. Hematopoietic rescue via T-cell-dependent, endogenous granulocyte-macrophage colony-stimulating factor induced by the pineal neurohormone melatonin in tumor-bearing mice. Cancer Res. 1994, 54, 2429-2432. [PubMed]

123. Blickenstaff, R.T.; Brandstadter, S.M.; Reddy, S.; Witt, R. Potential radioprotective agents. 1. Homologs of melatonin. J. Pharm. Sci. 1994, 83, 216-218. [CrossRef] [PubMed]

124. Vijayalaxmi; Meltz, M.L.; Reiter, R.J.; Herman, T.S.; Kumar, K.S. Melatonin and protection from whole-body irradiation: Survival studies in mice. Mutat. Res. 1999, 425, 21-27. [CrossRef]

125. Iwata, M.; Iwakawa, M.; Noda, S.; Ohta, T.; Minfu, Y.; Kimura, T.; Shibuya, H.; Imai, T. Correlation between single nucleotide polymorphisms and jejunal crypt cell apoptosis after whole body irradiation. Int. J. Radiat. Biol. 2007, 83, 181-186. [CrossRef] [PubMed]

126. Jang, S.S.; Kim, W.D.; Park, W.Y. Melatonin exerts differential actions on X-ray radiation-induced apoptosis in normal mice splenocytes and Jurkat leukemia cells. J. Pineal Res. 2009, 47, 147-155. [CrossRef] [PubMed]

127. Badr, F.M.; El Habit, O.H.; Harraz, M.M. Radioprotective effect of melatonin assessed by measuring chromosomal damage in mitotic and meiotic cells. Mutat. Res. 1999, 444, 367-372. [CrossRef]

128. Mornjakovic, Z.; Alicelebic, S.; Bilalovic, N.; Susko, I. Morphometric characteristics of leydig cells after total irradiation of rats treated with melatonin. Med. Arh. 1998, 52, 183-184. [PubMed]

129. Kim, J.K.; Lee, C.J. Effect of exogenous melatonin on the ovarian follicles in $\gamma$-irradiated mouse. Mutat. Res. 2000, 449, 33-39. [CrossRef]

130. Kim, J.K.; Lee, C.J.; Song, K.W.; Do, B.R.; Yoon, Y.D. $\gamma$-radiation accelerates ovarian follicular atresia in immature mice. In Vivo 1999, 13, 21-24. [PubMed]

131. Kundurovic, Z.; Mornjakovic, Z. Morphometric characteristics of thyroid cells in irradiation-stressed rats treated with pinealectomy and melatonin. Med. Arh. 1992, 46, 9-10. [PubMed]

132. Ruifrok, A.C.; Weil, M.M.; Thames, H.D.; Mason, K.A. Diurnal variations in the expression of radiation-induced apoptosis. Radiat. Res. 1998, 149, 360-365. [CrossRef] [PubMed]

133. Hussein, M.R.; Abu-Dief, E.E.; Kamel, E.; Abou El-Ghait, A.T.; Abdulwahed, S.R.; Ahmad, M.H. Melatonin and roentgen irradiation-induced acute radiation enteritis in albino rats: An animal model. Cell. Biol. Int. 2008, 32, 1353-1361. [CrossRef] [PubMed]

134. Onal, C.; Kayaselcuk, F.; Topkan, E.; Yavuz, M.; Bacanli, D.; Yavuz, A. Protective effects of melatonin and octreotide against radiation-induced intestinal injury. Dig. Dis. Sci. 2011, 56, 359-367. [CrossRef] [PubMed]

135. Khan, S.; Adhikari, J.S.; Rizvi, M.A.; Chaudhury, N.K. Radioprotective potential of melatonin against ${ }^{60}$ Co $\gamma$-ray-induced testicular injury in male C57BL/6 mice. J. Biomed. Sci. 2015, 22, 61. [CrossRef] [PubMed]

136. Vijayalaxmi; Reiter, R.J.; Tan, D.X.; Herman, T.S.; Thomas, C.R., Jr. Melatonin as a radioprotective agent: A review. Int. J. Radiat. Oncol. Biol. Phys. 2004, 59, 639-653. [CrossRef] [PubMed]

137. Vijayalaxmi; Thomas, C.R., Jr.; Reiter, R.J.; Herman, T.S. Melatonin: From basic research to cancer treatment clinics. J. Clin. Oncol. 2002, 20, 2575-2601. [CrossRef] [PubMed]

138. Kobashigawa, S.; Kashino, G.; Suzuki, K.; Yamashita, S.; Mori, H. Ionizing radiation-induced cell death is partly caused by increase of mitochondrial reactive oxygen species in normal human fibroblast cells. Radiat. Res. 2015, 183, 455-464. [CrossRef] [PubMed]

139. Zhou, R.; Yazdi, A.S.; Menu, P.; Tschopp, J. A role for mitochondria in NLRP3 inflammasome activation. Nature 2011, 469, 221-225. [CrossRef] [PubMed]

140. Potten, C.S. A comprehensive study of the radiobiological response of the murine (BDF1) small intestine. Int. J. Radiat. Biol. 1990, 58, 925-973. [CrossRef] [PubMed] 
141. Ramachandran, A.; Madesh, M.; Balasubramanian, K.A. Apoptosis in the intestinal epithelium: Its relevance in normal and pathophysiological conditions. J. Gastroenterol. Hepatol. 2000, 15, 109-120. [CrossRef] [PubMed]

142. Lissoni, P.; Bolis, S.; Brivio, F.; Fumagalli, L. A phase II study of neuroimmunotherapy with subcutaneous low-dose IL-2 plus the pineal hormone melatonin in untreatable advanced hematologic malignancies. Anticancer Res. 2000, 20, 2103-2105. [PubMed]

143. Hong, Y.; Won, J.; Lee, Y.; Lee, S.; Park, K.; Chang, K.T. Melatonin treatment induces interplay of apoptosis, autophagy, and senescence in human colorectal cancer cells. J. Pineal Res. 2014, 56, 264-274. [CrossRef] [PubMed]

144. Ma, Z.; Yang, Y.; Fan, C.; Han, J.; Wang, D.; di, S.; Hu, W.; Liu, D.; Li, X.; Reiter, R.J.; et al. Melatonin as a potential anticarcinogen for non-small-cell lung cancer. Oncotarget 2016, 7, 46768-46784. [CrossRef] [PubMed]

145. Trubiani, O.; Recchioni, R.; Moroni, F.; Pizzicannella, J.; Caputi, S.; Di Primio, R. Melatonin provokes cell death in human B-lymphoma cells by mitochondrial-dependent apoptotic pathway activation. J. Pineal Res. 2005, 39, 425-431. [CrossRef] [PubMed]

146. Miller, S.C.; Pandi-Perumal, S.R.; Esquifino, A.I.; Cardinali, D.P.; Maestroni, G.J. The role of melatonin in immuno-enhancement: Potential application in cancer. Int. J. Exp. Pathol. 2006, 87, 81-87. [CrossRef] [PubMed]

147. Hevia, D.; Gonzalez-Menendez, P.; Quiros-Gonzalez, I.; Miar, A.; Rodriguez-Garcia, A.; Tan, D.X.; Reiter, R.J.; Mayo, J.C.; Sainz, R.M. Melatonin uptake through glucose transporters: A new target for melatonin inhibition of cancer. J. Pineal Res. 2015, 58, 234-250. [CrossRef] [PubMed]

148. Blask, D.E.; Sauer, L.A.; Dauchy, R.T.; Holowachuk, E.W.; Ruhoff, M.S.; Kopff, H.S. Melatonin inhibition of cancer growth in vivo involves suppression of tumor fatty acid metabolism via melatonin receptor-mediated signal transduction events. Cancer Res. 1999, 59, 4693-4701. [PubMed]

149. Tischer, E.; Mitchell, R.; Hartman, T.; Silva, M.; Gospodarowicz, D.; Fiddes, J.C.; Abraham, J.A. The human gene for vascular endothelial growth factor. Multiple protein forms are encoded through alternative exon splicing. J. Biol. Chem. 1991, 266, 11947-11954. [PubMed]

150. Park, S.Y.; Jang, W.J.; Yi, E.Y.; Jang, J.Y.; Jung, Y.; Jeong, J.W.; Kim, Y.J. Melatonin suppresses tumor angiogenesis by inhibiting HIF-1 $\alpha$ stabilization under hypoxia. J. Pineal Res. 2010, 48, 178-184. [CrossRef] [PubMed]

151. Su, S.C.; Hsieh, M.J.; Yang, W.E.; Chung, W.H.; Reiter, R.J.; Yang, S.F. Cancer metastasis: Mechanisms of inhibition by melatonin. J. Pineal Res. 2017, 62. [CrossRef] [PubMed]

(C) 2017 by the authors. Licensee MDPI, Basel, Switzerland. This article is an open access article distributed under the terms and conditions of the Creative Commons Attribution (CC BY) license (http:/ / creativecommons.org/licenses/by/4.0/). 